\title{
Pemanfaatan Ekstrak Kulit Melinjo Merah (Gnetum Gnemon) sebagai Pewarna Alami pada Pembuatan Lipstik
}

\author{
Yusraini Dian Inayati Siregar ${ }^{*}$, Putri Utami \\ Program Studi Kimia Fakultas Sains dan Teknologi UIN Syarif Hidayatullah Jakarta \\ J1. Ir. H. Juanda No. 95 Ciputat Indonesia 15412 \\ *Email : yuskimia@uinjkt.ac.id
}

\begin{abstract}
Abstrak
Kulit melinjo merah atau Gnetum gnemon memiliki potensi untuk dimanfaatkan sebagai alternatif pewarna alami karena memiliki warna menarik yang disebabkan adanya pigmen karotenoid suatu turunan senyawa terpenoid. Karotenoid dapat dimanfaatkan sebagai pewarna alami dalam sediaan lipstik. Formulasi sediaan lipstik terdiri dari beberapa komponen diantaranya beeswax, lemak coklat, parafin, essen jeruk, minyak jarak, serta penambahan kulit melinjo merah dengan konsentrasi 36.7\%, 33.3\%, 40\% dan 53.5\%. Pembuatan ekstrak kulit melinjo merah dilakukan dengan metode maserasi shaker $300 \mathrm{rpm}$ selama 4 jam dengan pelarut minyak kelapa perbandingan 1:2 $(\mathrm{g} / \mathrm{ml})$. Uji terhadap sediaan yang dibuat berupa pemeriksaan mutu fisik sediaan mencakup homogenitas, titik leleh, stabilitas terhadap perubahan bentuk, warna dan aroma selama penyimpanan 30 hari pada suhu ruang, oles, $\mathrm{pH}$, uji iritasi dan kesukaan. Formulasi sediaan lipstik dengan ekstrak kulit melinjo merah cukup stabil, homogen, $\mathrm{pH}$ 3.8-4.7 (mendekati $\mathrm{pH}$ kulit), titik leleh 53-54.5 ${ }^{\circ} \mathrm{C}$ sesuai dengan kriteria SNI 16479-1998 (50-70 ${ }^{\circ} \mathrm{C}$ ) mudah dioleskan dengan warna yang merata, serta tidak menyebabkan iritasi sehingga cukup aman untuk digunakan, dan keempat formulasi memiliki daya terima yang baik.
\end{abstract}

Kata kunci: Karotenoid, kulit melinjo merah (Gnetum gnemon), lipstik.

\begin{abstract}
Red melinjo' rind (Gnetum gnemon) is potential to be used as the alternative natural colouring material for making lipstick. The red colour from melinjo's rind was caused by carotenoid pigment which is terpenoid's derivative compounds. Carotenoid has many advantages, one of them is can be used to replace synthetic coloring material for lipstick. Lipstick material consisted of some component : beeswax, brown fat, paraffin, orange essence, jarak oil, and by adding red melinjo's rind with concentration of $36.7 \%, 33.3 \%, 40 \%$ and $53.5 \%$. The making of extract from simpilicia's red melinjo's rind by using shaker maceration 300 rpm for 4 hour with coconut oil as a solvent with ratio 1:2 (g/ml). Lipstick's evaluation test consisted of physical quality examination, homogeneity examination, melting point examination, stability test for deformation, colour and flavor during 30 days keeping in a room temperature, smear test, and $\mathrm{pH}$ examination, iritation test, and hedonic test. Lipstick formulation used red melinjo's skin extract as colouring material shows enough stability, homogeneity, $\mathrm{pH} 3.8-4.7$ (come near to skin's $\mathrm{pH}$ ), melting point was $53-54.5^{\circ} \mathrm{C}$ which is appropriate with SNI criteria 16-479-1998 (50-70 $\left.{ }^{\circ} \mathrm{C}\right)$, easy to smeared with prevalent color, and it doesn't cause iritation, so it is safe, and the four formulation has good received power in hedonic test.
\end{abstract}

Keywords : Carotenoid, lipstick, red melinjo's rind

\section{PENDAHULUAN}

Gnetum gnemon dikenal dengan nama lokal melinjo tersebar luas di Indonesia. Penyebaran pohon melinjo di daerah Andaman, Sumatra dan pulau Jawa. Hampir semua bagian pohon melinjo dapat dimanfaatkan, terutama bagian buah dan daunnya digunakan sebagai bahan makanan. Biji melinjo biasa digunakan sebagai bahan dasar pembuatan emping dan bahan tambahan dalam sayur. Daerah penghasil emping melinjo tersebar di Pandeglang-Banten, Batang-Jawa Tengah dan Bantul-Yogyakarta. Pemanfaatan biji melinjo menyisakan kulit melinjo yang belum dimanfaatkan secara sempurna. Kulit melinjo lebih banyak dimanfaatkan dalam bentuk basah atau segar, diolah menjadi sayuran atau digoreng menjadi kripik (Imelda 2007). Tetapi biasanya bahan yang masih 
mengandung air (dalam bentuk basah) tidak awet dan mudah busuk.

Oleh sebab itu, dicari pemanfaatan lain yang bisa lebih tahan lama yaitu dengan cara dikeringkan. Kulit luar buah melinjo sedikit lunak dan berwarna kuning hingga merah keunguan atau jingga kemerahan. Berdasarkan sifat fisik ini, dapat diketahui bahwa kulit melinjo memiliki kandungan warna alami yang bisa dimanfaatkan sebagai pewarna alami pada makanan, obat dan kosmetik.

Penelitian ini bertujuan untuk mengetahui jenis pelarut yang sesuai untuk mengekstraksi pigmen warna dari kulit melinjo merah untuk dimanfaatkan sebagai pewarna lipstik, menentukan formulasi lipstik dengan penambahan pigmen alami dan mengetahui mutu lipsti yang dihasilkan dan mengetahui tingkat kesukaan sediaan lipstik dan sediaan lipstik menggunakan ekstrak kulit melinjo merah tidak menyebabkan iritasi saat digunakan.

\section{METODE PENELTIAN}

Alat-alat yang digunakan pada penelitian ini adalah evaporator, oven, timbangan analitik, melting point, magnetic stirer, kertas saring, termometer, hot plate, blender, spekrofotometer UV-Vis, alat-alat gelas dan pengayak. Bahan yang digunakan dalam penelitian ini adalah kulit melinjo merah (Gnetum gnemon), etanol, aseton, heksan dan minyak kelapa, beeswax, parafin, minyak jarak, lemak coklat, essen jeruk.

\section{Ekstraksi kulit Melinjo Merah}

Kulit melinjo disortasi hanya utuk memperoleh kulit melinjo merah. Kulit melinjo merah dikering anginkan, diblender kering dan diayak. Ekstraksi dilakukan dengan metode maserasi menggunakan pelarut etanol, aseton, heksan dan minyak kelapa, tanpa pemanasan dengan pengadukkan shaker $300 \mathrm{rpm}$ dan agar tidak terkena sinar matahari atau pancaran cahaya diminimalisasi dengan penggunaan alumunium foil sebagai pelapis wadah.

Hasil maserasi disaring mengunakan kertas saring kemudian filtrat dievaporasi dengan rotary evaporator hingga diperoleh ekstrak etanol, aseton dan heksan pekat. Ekstraksi ini juga dilakukkan menggunakan minyak kelapa tanpa pemekatan.

\section{Uji Fitokimia}

Skrining fitokimia dilakukan terhadap senyawa alkaloida, flavonoida, terpenoida/ steroida, tanin dan saponin menurut prosedur yang telah dilakukan oleh Harbone (Harbone 1987).

\section{Penentuan Panjang Gelombang Maksimum Ekstrak}

Penentuan panjang gelombang maksimum ekstrak kulit melinjo merah dilakukan menggunakan spektrofotometer visible pada panjang gelombang 400-520 nm. Sebanyak $5 \mathrm{ml}$ ekstrak etanol, aseton, heksan dan minyak kelapa.

\section{Uji Dispersi Pigmen}

Uji dispersi dilakukan untuk menguji kemampuan dispersi ekstrak dalam lipstik. Pada uji ini, pigmen didispersikan dalam minyak jarak. Parameter uji meliputi homogenitas pigmen, butiran (gritty) dan pengendapan pigmen. Hasil dispersi dari ekstrak terbaik digunakan dalam formulasi.

\section{Optimisasi Pelarut}

Hasil ekstraksi diuji absorbansinya dengan spektrofotometer visible pada panjang gelombang maksimum 429 dan $478 \mathrm{~nm}$ (ekstrak etanol) dan minyak kelapa kulit melinjo merah. Proses ekstraksi menggunakan pelarut etanol dan minyak kelapa dilakukan pada perbandingan sampel dengan pelarut ( $\mathrm{g} / \mathrm{ml}) 1: 2,1: 3$, dan 1:4 pada temperatur ruang dengan pengadukan shaker $300 \mathrm{rpm}$. Hasil ekstraksi diuji absorbansinya dengan spektrofotometer visible setiap satu jam.

\section{Formulasi dan Pembuatan Lipstik}

Formulasi dasar dilakukan dengan perlakuan yaitu penggunaan konsentrasi ekstrak zat warna dalam minyak kelapa dengan minyak jarak (tabel 1). 
Tabel 1 Formulasi lipstik

\begin{tabular}{lcccc}
\hline Komponen & \multicolumn{4}{c}{ Formulasi } \\
& 436 & 790 & 158 & 632 \\
\hline Pigmen & $4.0 \mathrm{~g}$ & $3.0 \mathrm{~g}$ & $2.5 \mathrm{~g}$ & $2.0 \mathrm{~g}$ \\
Warna & & & & \\
Beeswax & $1.5 \mathrm{~g}$ & $1.5 \mathrm{~g}$ & $1.5 \mathrm{~g}$ & $1.5 \mathrm{~g}$ \\
Lemak & $0.5 \mathrm{~g}$ & $0.5 \mathrm{~g}$ & $0.5 \mathrm{~g}$ & $0.5 \mathrm{~g}$ \\
Cokelat & & & & \\
Parafin & $1.0 \mathrm{~g}$ & $1.0 \mathrm{~g}$ & $1.0 \mathrm{~g}$ & $1.0 \mathrm{~g}$ \\
Minyak & 0 & $1.0 \mathrm{~g}$ & $1.5 \mathrm{~g}$ & $2.0 \mathrm{~g}$ \\
Jarak & & & & \\
Esen Jeruk & $0.5 \mathrm{~g}$ & $0.5 \mathrm{~g}$ & $0.5 \mathrm{~g}$ & $0.5 \mathrm{~g}$ \\
Jumlah & $7.5 \mathrm{~g}$ & $7.5 \mathrm{~g}$ & $7.5 \mathrm{~g}$ & $7.5 \mathrm{~g}$ \\
\hline
\end{tabular}

\section{a. Massa 1}

Dimasukkan beeswax kedalam cawan dan ditambahkan parafin dan lemak coklat. Semua campuran dalam cawan penguap dilebur di atas penangas air temperatur $85^{\circ} \mathrm{C}$. b. Massa 2

Lumpang direndam dengan air panas, \pm 10 -15 menit, kemudian lumpang dikeringkan dan lapisi dengan sedikit minyak jarak sampai menutupi permukaan bagian dalam lumpang. Tambahkan ekstrak kulit melinjo merah, diaduk homogen. Kemudian tambahkan minyak jarak dan campuran diaduk homogen.

c. Campuran

Massa 1 yang telah lebur ditambahkan ke dalam massa 2, diaduk homogen, sampai campuran sudah mulai agak mengental. Ditambahkan essen jeruk ke dalam campuran dan diaduk homogen. Segera tuangkan campuran ke dalam cetakan lipstik dan dinginkan dibiarkan membeku.

\section{Evaluasi Sedian Lipstik}

Pemeriksaan mutu fisik meliputi pemeriksaan homogenitas, titik leleh, uji oles, pemeriksaan $\mathrm{pH}$, uji iritasi, uji kesukaan dan stabilitas sediaan yang mencakup pengamatan terhadap perubahan bentuk, warna dan bau dari sediaan,.

\section{Uji Titik Leleh}

Sampel dimasukkan ke dalam pipa kapiler yang berdiameter satu millimeter kemudian dimasukkan ke alat melting point untuk dipanaskan. Suhu yang dicatat adalah suhu saat sampel mulai meleleh. Sediaan lipstik yang baik sesuai dengan SNI 16-47691998.

\section{Pemeriksaan pH Sediaan}

Alat $\mathrm{pH}$ meter terlebih dahulu dikalibrasi dengan menggunakan larutan bufer standar netral $(\mathrm{pH}$ 7.01) dan larutan bufer $\mathrm{pH}$ asam ( $\mathrm{pH}$ 4.01) hingga alat menunjukkan harga $\mathrm{pH}$ tersebut. Kemudian elektroda dicuci dengan air suling, lalu dikeringkan dengan tissue. Sampel dibuat dalam konsentrasi $1 \%$ yaitu ditimbang $1 \mathrm{~g}$ sediaan dan dilebur dalam beker glass dengan $100 \mathrm{ml}$ air suling di atas penangas air. Setelah dingin kemudian elektroda dicelupkan dalam larutan tersebut. Dibiarkan alat menunjukkan harga $\mathrm{pH}$ sampai konstan. Angka yang ditunjukkan $\mathrm{pH}$ meter merupakan $\mathrm{pH}$ sediaan. Penentuan $\mathrm{pH}$ dilakukan tiga kali pada tiga lipstik terhadap masingmasing konsentrasi (Rawlins 2003).

\section{Uji Oles}

Uji oles dilakukan secara visual dengan cara mengoleskan lipstik pada kulit punggung tangan kemudian mengamati banyaknya warna yang menempel dengan perlakuan 5 kali pengolesan. Sediaan lipstik dikatakan mempunyai daya oles yang baik jika warna yang menempel pada kulit punggung tangan banyak dan merata dengan beberapa kali pengolesan pada tekanan tertentu. Pemeriksaan dilakukan terhadap masingmasing sediaan yang dibuat dan dioleskan pada kulit punggung tangan dengan 5 kali pengolesan (Keithler 1956).

\section{Pemeriksaan Homogenitas}

Masing-masing sediaan lipstik yang dibuat diperiksa homogenitasnya dengan cara mengoleskan sejumlah tertentu sediaan pada kaca yang transparan. Sediaan harus menunjukkan susunan yang homogen dan tidak terlihat adanya butir-butir kasar (Ditjen POM 1979).

\section{Uji Hedonik}

Uji kesukaan atau hedonic test terhadap keempat sediaan lipstik dilakukan terhadap 20 orang pengguna lipstik. Parameter yang diujikan adalah tekstur, warna, dan aroma mengunakan skala hedonik yang berkisar antara 1 sampai 5, dimana (5) Sangat Suka, (4) Suka, (3) Agak Suka, (2) Tidak Suka, (1) Sangat Tidak Suka.

\section{Uji Iritasi}


Uji iritasi dilakukan terhadap sediaan lipstik yang dibuat dengan maksud untuk mengetahui bahwa lipstik yang dibuat dapat menimbulkan iritasi pada kulit atau tidak. Iritasi dapat dibagi menjadi 2 kategori, yaitu iritasi primer yang akan segera timbul sesaat setelah terjadi pelekatan atau penyentuhan pada kulit, dan iritasi sekunder yang reaksinya baru timbul beberapa jam setelah penyentuhan atau pelekatan pada kulit (Ditjen POM 1985).

Teknik yang digunakan pada uji iritasi ini adalah uji tempel terbuka (Patch Test) pada lengan bawah bagian dalam terhadap 10 orang panelis. Uji tempel terbuka dilakukan dengan mengoleskan sediaan yang dibuat pada lokasi lekatan dengan luas tertentu $(2.5 \times 2.5 \mathrm{~cm})$, dibiarkan terbuka dan diamati apa yang terjadi. Kriteria panelis uji iritasi sesuai dengan Ditjen POM 1985. Uji ini dilakukan sebanyak 3 kali sehari selama tiga hari selama 10 menit untuk setiap sediaan, reaksi yang terjadi diamati. Reaksi iritasi positif ditandai oleh adanya kemerahan, gatal-gatal, atau bengkak pada kulit lengan bawah bagian dalam yang diberi perlakuan. Adanya kulit merah diberi nilai (1), gatal-gatal (2), bengkak (3), dan yang tidak menunjukkan reaksi apa-apa diberi nilai (0).

\section{Pemeriksaan Stabilitas Sediaan}

Pemeriksaan stabilitas sediaan dilakukan terhadap adanya perubahan bentuk, warna dan bau dari sediaan lipstik dilakukan terhadap masingmasing sediaan selama penyimpanan pada suhu kamar pada hari ke 1 , 5, 10 dan selanjutnya setiap 5 hari hingga hari ke-30. Pada perubahan bentuk diperhatikan apakah lipstik terjadi perubahan bentuk dari bentuk awal pencetakan atau tidak, pada perubahan warna diperhatikan apakah lipstick terjadi perubahan warna dari warna awal pembuatan lipstik atau tidak, pada perubahan bau diperhatikan apakah lipstik masih berbau khas dari parfum yang digunakan atau tidak (Vishwakarma 2011).

\section{HASIL DAN PEMBAHASAN}

\section{Ekstraksi}

Ekstraksi yang dilakukan dengan metode maserasi dengan pengadukan. Kulit melinjo merah yang sudah dikeringkan, selanjutnya digiling halus bertujuan untuk menurunkan kandungan air yang terdapat dalam kulit melinjo merah dan untuk mendapatkan rendemen ekstrak yang lebih besar sedangkan penggilingan dan pengayakan dimaksudkan agar partikel bahan baku memiliki ukuran partikel yang sama dan luas permukaan yang lebih besar sehingga senyawa yang diekstraksi dapat lebih mudah ditarik keluar dari bahan serta mempermudah kontak antara bahan dan pelarut. Maserasi dengan pengadukkan shaker 300 rpm dilakukan untuk mempercepat waktu ekstraksi sedangkan tanpa pemanasan dan wadah ditutup dengan alumunium foil saat proses ekstraksi dimaksudkan untuk menjaga komponen yang sensitif terhadap panas dan meminimalisasi kerusakan komponen dalam sampel akibat oksidasi dan fotooksidasi. Metode maserasi dipilih didasarkan pada sifat kelarutannya dari komponen didalam pelarut yang digunakan.

Ekstraksi zat warna menggunakan ketiga pelarut yaitu etanol, aseton dan heksan berdasarkan perbedaan tingkat kepolaran. Tabel 2 menunjukkan bahwa pelarut etanol menghasilkan rendemen paling tinggi sebesar $10.32 \%$. Hal ini menunjukkan bahwa jenis pelarut yang digunakan mempengaruhi jumlah rendemen yang dihasilkan. Komponen kulit melinjo merah yang banyak mengandung metabolit sekunder yang bersifat polar. Hasil ekstraksi zat warna dari kulit melinjo merah disajikan pada tabel 2 .

Tabel 2 Rendemen ekstrak kulit melinjo merah

\begin{tabular}{cccc}
\hline Pelarut & Berat sampel (g) & $\begin{array}{c}\text { Ekstrak } \\
\text { Pekat }(\mathrm{g})\end{array}$ & \% Rendemen \\
\hline Etanol & 75 & 7.74 & $10.32 \%$ \\
Aseton & 204 & 15.74 & $7.71 \%$ \\
Heksan & 100 & 0.7 & $0.70 \%$ \\
\hline
\end{tabular}

Warna yang dihasilkan oleh ekstrak kulit melinjo merah diduga golongan karotenoid karena warna-warna yang dihasilkan dari ekstraksi tersebut adalah oranye-merah. Menurut Cornelia (2009) bahwa buah melinjo mengandung karotenoid (pro vitamin A) sebanyak 1000 SI dan vitamin C sebanyak $100 \mathrm{mg}$ yang berasal dari kulit buah melinjo. Ekstraksi pelarut etanol memnghasilkan rendemen tertinggi yaitu $10.87 \%$ yang menghasilkan total karoten $241.220 \mathrm{ppm}$ (beta karoten $185.275 \mathrm{ppm}$ ), vitamin C $9.230(\mathrm{mg} / 100 \mathrm{ml})$ dan aktivitas antioksidan (IC 50) $28.43 \mathrm{mg}$, serta Likopen $12.130 \mathrm{mg} / 100$ gram. Berdasarkan data 
tersebut, maka kulit melinjo merah mempunyai potensi sebagai pewarna alami.

Uji fitokimia dilakukan pada simplisia sampel. Hasil pengujian disajikan pada tabel 3.

Tabel 3 Uji fitokimia ekstrak kulit melinjo merah

\begin{tabular}{lc}
\hline \multicolumn{1}{c}{ Parameter } & Hasil Uji Fitokimia \\
\hline Alkaloid & Negatif \\
Flavonoid & Positif \\
Tannin & Positif \\
Kuinon & Positif \\
Terpenoid & Positif \\
Saponin & Negatif \\
\hline
\end{tabular}

Kulit melinjo merah mengandung flavonoid, tanin, kuinolin dan terpenoid. Flavonoid merupakan senyawa fenolik alam yang potensial sebagai antioksidan. Tanin merupakan salah satu jenis senyawa yang termasuk kedalam golongan polifenol, memiliki sifat dapat membentuk kompleks dengan protein dan juga sebagai pengkelat logam.

Karotenoid merupakan salah satu contoh senyawa metabolit sekunder dari jenis terpenoid, kelompok pigmen alami yang berwarna merah, oranye atau kuning dan larut dalam lipid. Ekstrak kulit melinjo merah merupakan senyawa berwarna sehingga pengukuran dilakukan pada daerah visible yaitu pada panjang gelombang 420-520 nm. Panjang gelombang maksimum $\left(\lambda_{\max }\right)$ ekstrak kulit melinjo merah disajikan pada tabel 4.

Tabel 4 Panjang gelombang maksimum $\left(\lambda_{\max }\right)$ ekstrak kulit melinjo merah

\begin{tabular}{cc}
\hline Ekstrak & Panjang Gelombang (nm) \\
\hline Etanol & 429 \\
Aseton & 423 \\
Heksan & 428 \\
Minyak Kelapa & 478 \\
\hline
\end{tabular}

Tabel 4 menunjukkan bahwa keempat ekstrak kulit melinjo merah tersebut mengandung karotenoid. Pigmen yang memiliki jangkauan spektrum tampak pada kisaran panjang gelombang 400-500 $\mathrm{nm}$ adalah karotenoid (Harborne 1987).
Berdasarkan daya larutnya dalam pelarut organik, karotenoid dapat digolongkan menjadi dua yaitu karoten dan xantofil. Karoten sangat larut dalam petroleum eter dan kurang larut dalam alkohol sedangkan xantofil sebaliknya dapat larut dalam alkohol (IPB1989). Karotenoid golongan xantofil diduga terdapat dalam ekstrak etanol kulit melinjo merah karena dapat larut dalam pelarut alkohol. Sedangkan karotenoid golongan karoten diduga terdapat dalam ekstrak heksan ataupun minyak kelapa karena memiliki tingkat kepolaran yang sama dengan pelarut petroleum eter yang bersifat nonpolar.

\section{Hasil Uji Dispersi Ekstrak}

Uji dispersi atau kelarutan dilakukan untuk menguji kemampuan ekstrak pewarna larut dalam basis lipstik. Basis lipstik yang digunakan adalah minyak jarak yang berfungsi sebagai pendispersi pigmen warna dengan variasi pelarut ekstrak (etanol, aseton, heksan dan ekstrak minyak kelapa). Hasil uji dispersi menunjukkan bahwa kelarutan keempat ekstrak kulit melinjo merah yang didispersikan dalam minyak jarak homogen, tidak berpasir atau grity. Ekstrak zat warna kulit melinjo merah pelarut polar maupun nonpolar dapat terdispersi dengan baik dalam basis lipstik yaitu minyak jarak. Hasil uji dispersi ekstrak pewarna kulit melinjo merah disajikan pada tabel 5.

Tabel 5 Hasil uji dispersi ekstrak kulit melinjo merah

\begin{tabular}{ccc}
\hline Ekstrak & $\begin{array}{c}\text { Dispersi Minyak } \\
\text { jarak }\end{array}$ & $\begin{array}{c}\text { Tingkat } \\
\text { Homogenitas }\end{array}$ \\
\hline Etanol & ++ & Tidak berpasir \\
Aseton & ++ & Tidak berpasir \\
Heksan & +++ & Tidak berpasir \\
Minyak Kelapa & +++ & Tidak berpasir \\
\hline
\end{tabular}

Keterangan: Mampu terdispersi (+)

Tabel 5 menunjukkan bahwa ekstrak heksan dan ekstrak minyak kelapa memiliki daya dispersi yang lebih baik dibandingkan pelarut ekstrak etanol dan ekstrak aseton dalam basis lipstik.

\section{Optimisasi Ekstrak Etanol}

Optimasi ekstrak kulit melinjo merah menggunakan pelarut etanol dilakukan karena ekstrak etanol memiliki rendemen tertinggi. 
Optimasi dilakukan untuk mendapatkan waktu optimum ekstraksi dengan mengetahui nilai serapan (absorbansi) ekstrak pada spektrofotometer visible. Optimasi ekstrak etanol disajikan pada gambar 1 .

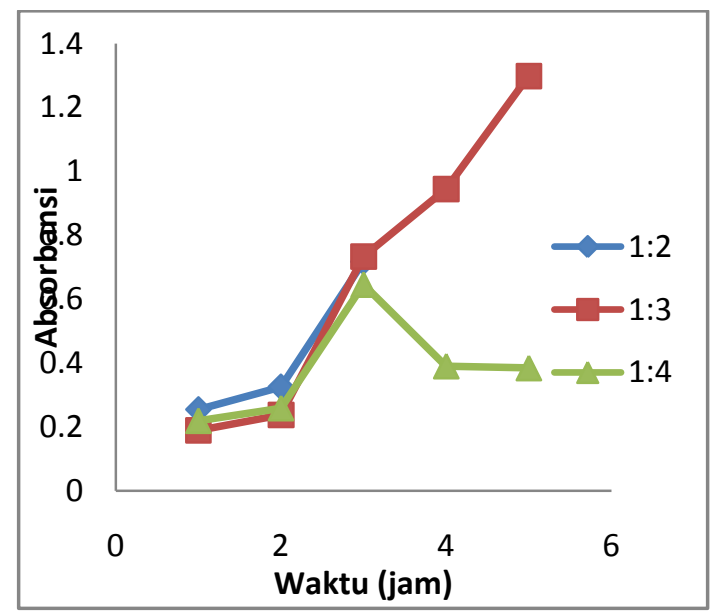

Gambar 1 Gambar optimasi ekstrak etanol kulit melinjo merah

Gambar 1 adalah grafik optimasi ekstrak etanol yang ditunjukkan oleh hubungan waktu saat maserasi terhadap nilai absorbansi. Optimasi ekstraksi dengan pelarut etanol dilakukan pada variasi perbandingan antara sampel (g) dengan pelarut $(\mathrm{ml})$ adalah sebesar $1: 2,1: 3$, dan 1:4 pada panjang gelombang maksimum $429 \mathrm{~nm}$ dan faktor pengenceran 20 kali. Nilai absorbansi maksimum terjadi pada perbandingan sampel/pelarut sebesar 1:3 waktu ekstraksi selama 3 jam dan nilai absorbansi adalah sebesar 0.7335 . Selanjutnya hasil optimasi perbandingan sampel/pelarut sebesar 1:3 waktu ekstraksi selama 3 jam digunakan dalam formulasi lipstik.

\section{Optimisasi Ekstrak Minyak Kelapa}

Optimisasi ekstrak kulit melinjo merah dari pelarut nonpolar yaitu pelarut minyak kelapa karena minyak kelapa termasuk kedalam basis lipstik. Optimasi dilakukan untuk mendapatkan waktu optimum ekstraksi dengan mengetahui nilai serapan (absorbans) ekstrak pada spektrofotometer visible. Optimisasi ekstrak minyak kelapa disajikan pada gambar 2.

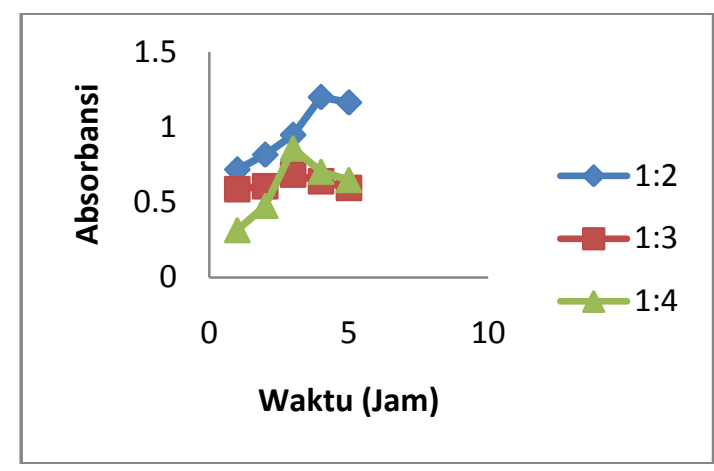

Gambar 2 Optimisasi ekstrak minyak kelapa kulit melinjo merah

Gambar 2 adalah optimasi ekstrak minyak kelapa yang ditunjukkan oleh hubungan waktu saat maserasi terhadap nilai absorbansi. Optimasi ekstraksi dengan pelarut minyak kelapa dilakukan pada variasi perbandingan antara sampel $(\mathrm{g})$ dengan pelarut (ml) adalah sebesar 1:2, 1:3 dan 1:4 pada panjang gelombang maksimum $478 \mathrm{~nm}$ dan faktor pengenceran 25 kali. Nilai absorbansi maksimum terjadi pada perbandingan sampel/pelarut sebesar 1:2 waktu ekstraksi selama 4 ja $\mathrm{m}$ dan nilai absorbansi adalah sebesar 1.1995. Selanjutnya hasil optimasi perbandingan sampel/pelarut sebesar 1:2 waktu ekstraksi selama 4 jam digunakan dalam formulasi lipstik.

\section{Formulasi dan Pembuatan Lipstik}

Ekstrak etanol kulit melinjo merah digunakan sebagai pewarna lipstik pada formulasi karena menghasilkan rendemen ekstrak tertinggi dan juga dapat terdispersi dengan baik pada basis lipstik yaitu minyak jarak sebagai pelarut pewarna. Ekstrak etanol yang digunakan adalah hasil optimasi perbandingan sampel/pelarut sebesar 1:3 waktu ekstraksi selama 3 jam. Pencampuran massa 1 (beeswax, parafin, dan lemak coklat) kedalam massa 2 (minyak jarak dan ekstrak etanol zat warna kulit melinjo merah) pada suhu $70{ }^{\circ} \mathrm{C}$ berlangsung homogen akan tetapi setelah didinginkan pada cetakkan tidak terjadi lipstik yang homogen dimana zat warna mengendap dibagian bawah lipstik. Pewarna ekstrak etanol kulit melinjo merah kurang terdispersi dengan baik sehingga menghasilkan sediaan lipstik yang tidak homogen, ini terjadi disebabkan ekstrak etanol kulit melinjo merah yang terlalu pekat dan sifatnya yang polar sehingga tidak 
dapat terdispersi dalam komponen lipstik lainnya yang bersifat nonpolar. Sediaan lipstik ekstrak etanol kulit melinjo merah dapat dilihat pada gambar 3 .
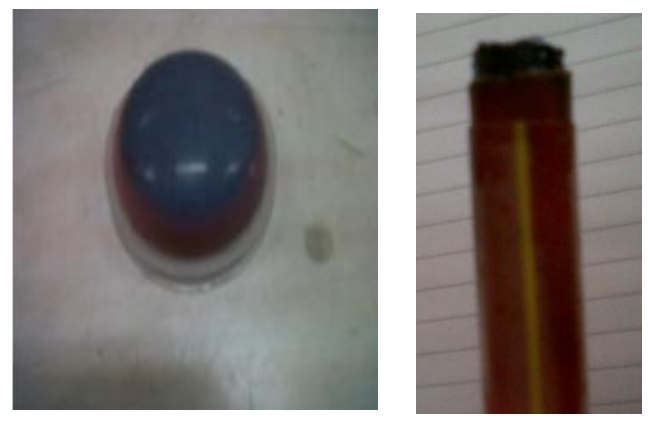

Gambar 3 Sediaan lipstik ekstrak etanol kulit melinjo merah

Sediaan lipstik ekstrak kulit melinjo merah yang tidak homogen dapat diatasi dengan menambahkan emulsifier yang tepat dalam formulasi lipstik tetapi hal ini tidak dilakukan karena membutuhkan studi lebih lanjut. Permasalahan ini diatasi dengan mengambil ekstrak pewarna kulit melinjo merah yang larut dalam pelarut nonpolar. Ekstrak yang digunakan pada formulasi adalah ekstrak minyak kelapa kulit melinjo merah. Preparasi ekstrak ini sedikit berbeda karena tidak dipekatkan melainkan zat warna yang larut pada minyak langsung diaplikasikan dalam formulasi.

Ekstrak minyak kelapa kulit melinjo merah dalam formulasi lipstik dengan variasi konsentrasi pigmen pewarna dan minyak jarak yang berbeda-beda dimaksudkan untuk mengetahui perbedaan intensitas warna dan pengaruhnya terhadap konsistensi lipstik dalam uji evaluasi sediaan.

Lemak coklat (oleum cacao) digunakan pada lipstik untuk memberikan kehalusan pada kulit bibir, mencegah efek kering, memberi lapisan pada bibir dan meningkatkan daya dispersi pigmen (Okayani 1990). Malam atau wax merupakan hal yang sangat penting dalam pembuatan lipstik. Hasil yang baik akan didapatkan dengan menggunakan campuran wax yang berbeda titik lelehnya (Howard 1974). Penelitian ini menggunakan dua macam wax yaitu beeswax dan parafin. Beeswax merupakan malam lebah yang diperoleh dari sarang lebah, malam lebah mempunyai titik leleh $62-64{ }^{\circ} \mathrm{C}$ (Dep Kes RI 1980). Parafin atau lilin putih memiliki bobot jenis 0,890 dan titik leleh $47{ }^{\circ} \mathrm{C}-66{ }^{\circ} \mathrm{C}$ yang tidak larut dalam air, tetapi larut dalam pelarut organik. Keduanya berfungsi untuk meningkatkan titik leleh lipstik dan memberi bentuk pada lipstik. Tabel formulasi lipstik yang digunakan dalam penelitian disajikan pada Tabel 7.

Tabel 7 Konsentrasi formulasi lipstik

\begin{tabular}{ccccc}
\hline Komponen & \multicolumn{4}{c}{ Formulasi } \\
& 436 & 790 & 158 & 632 \\
\hline Pigmen Warna & $53.3 \%$ & $40 \%$ & $33.3 \%$ & $26.7 \%$ \\
Minyak Jarak & 0 & $13.3 \%$ & $20 \%$ & $26.7 \%$ \\
Beeswax & \multicolumn{2}{c}{$20 \%$} \\
Lemak Coklat & $6.7 \%$ \\
Parafin & $13.3 \%$ \\
Esen Jeruk & $6.7 \%$ \\
Jumlah & $100 \%$ \\
\hline
\end{tabular}

Penelitian ini menggunakan konsentrasi wax sebesar $33.3 \%$ yaitu dengan komposisi beeswax sebesar $20 \%$ dan parafin sebesar $13.3 \%$. Penggunaan wax pada konsentrasi ini berdasarkan pada penelitian yang telah dilakukan oleh Martinalova (2004) perbandingan konsentrasi wax sebesar 34\% dan minyak jarak konsentrasi sebesar 26\% menghasilkan lipstik yang keras dan kurang berminyak.

Lipstik yang memenuhi persyaratan adalah lipstik yang tidak rapuh, tidak terlalu keras dan tidak terlalu lunak (Imron, 1985). Keras lunaknya suatu lipstik dipengaruhi oleh konsentrasi wax. Penggunaan wax tdak boleh berlebihan karena akan menyebabkan daya retak yang tinggi. Standar DepKes RI dalam penggunaan wax berkisar pada konsentrasi 10\%-50\% yaitu dengan minimal titik leleh $42^{\circ} \mathrm{C}$. Lipstik dengan konsentrasi wax $40 \%$ $50 \%$ tergolong lipstik keras dan untuk lipstik dengan konsentrasi pada kisaran 30\% bertekstur agak kasar.

Minyak jarak merupakan minyak yang diperoleh dari pemerasan biji Ricirus communis yang telah dikupas. Minyak jarak digunakan untuk mendispersikan zat warna secara merata. Minyak jarak mempunyai viskositas yang tinggi yang sangat menguntungkan didalam pengaturan warna lipstik dan kelenturan. Viskositas yang tinggi ini dapat menghambat proses pembasahan pigmen karena tegangan permukaan menjadi 
tinggi (Balsam et al. 1974). Penggunaan minyak jarak juga perlu dibatasi karena jika berlebihan akan menyebabkan rasa yang tidak enak dan kesat selama pemakaian lipstik (Howard 1974).

Peningkatan kekerasan lipstik terjadi karena subsitusi minyak jarak dengan wax. Konsentrasi wax yang ditambahkan dapat meningkatkan jumlah padatan dalam emulsi sehingga produk lipstik yang terbentuk akan semakin keras sebaliknya penambahan minyak jarak akan menambah jumlah cairan dan emulsi sehingga produk lipstik yang terbentuk akan semakin lunak dan creamy (Perdanakusumah et al. 2003).

Minyak kelapa mempunyai viskositas lebih rendah sehingga minyak kelapa digunakan untuk mengurangi viskositas dan tegangan permukaan pada campuran. Peningkatan konsentrasi ekstrak pewarna kedalam formulasi lipstik dilakukan untuk mengetahui pengaruh peningkatan konsentrasi ekstrak pewarna yang ditambahkan. Penambahan konsentrasi pewarna dapat dilihat pada tabel 13 sehingga menghasilkan produk lipstik yang disajikan pada Gambar 4.

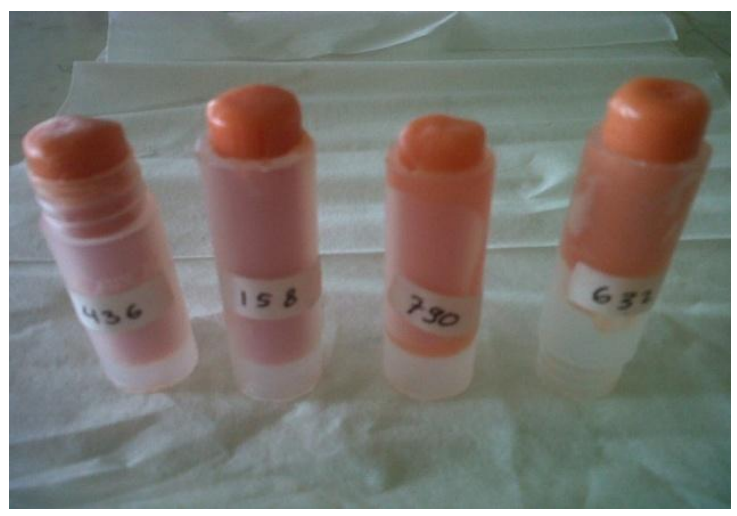

Gambar 4 Produk lipstik ekstrak minyak kelapa kulit melinjo merah

Warna-warna lipstik yang terlihat pada gambar 4 merupakan warna yang tampak secara visual yaitu oranye. Warna oranye yang dihasilkan oleh sediaan lipstik merupakan pigmen karotenoid.

\section{Titik Leleh}

Titik leleh lipstik dipengaruhi oleh komponen penyusun lipstik seperti konsentrasi wax, lemak dan minyak. Penelitian ini menggunakan komponen campuran wax yaitu beeswax yang mempunyai titik leleh $62-64{ }^{\circ} \mathrm{C}$ dan parafin yang mempunyai titik leleh $66^{\circ} \mathrm{C}$, lemak dengan lemak coklat yang mempunyai titik leleh $35{ }^{\circ} \mathrm{C}$ dan campuran minyak yaitu minyak jarak dan minyak kelapa.

Hasil yang baik akan diperoleh dengan mengunakan campuran wax tidak lebih dari 50\% karena akan menghasilkan lipstik yang keras sedangkan konsentrasi minyak dapat menurunkan titik leleh lipstik (Howard 1974). Titik leleh yang diperoleh dari keempat formulasi sediaan lipstik disajikan pada Tabel 8.

Tabel 8 Titik leleh sedian lipstik ekstrak minyak kelapa kulit melinjo merah

\begin{tabular}{ccccc}
\hline Formulasi & \multicolumn{4}{c}{ Titik Leleh $\left({ }^{\circ} \mathrm{C}\right)$} \\
& $\mathrm{T}_{0}$ & $\mathrm{~T}_{1}$ & $\begin{array}{c}\mathrm{Tc} \\
\left(\left(\mathrm{T}_{0}+\mathrm{T}_{1}\right) / 2\right)\end{array}$ & $\begin{array}{r}\mathrm{SNI} \\
1998\end{array}$ \\
\hline 436 & 53 & 54 & 53.5 \\
158 & 54 & 55 & 54.5 & \\
790 & 53 & 54 & 53.5 & $50-70$ \\
632 & 53 & 54 & 53.5 & \\
\hline
\end{tabular}

Tabel 8 menunjukkan bahwa keempat formulasi lipstik yang dibuat mempunyai titik leleh yang tidak jauh berbeda yaitu pada kisaran 53-54.5 ${ }^{\circ} \mathrm{C}$. Keempat sediaan lipstik memiliki konsentrasi yang sama untuk wax sebesar $33.3 \%$, lemak sebesar $6.7 \%$ dan minyak sebesar $53.3 \%$. Terjadinya peningkatan titik leleh pada formulasi 158 yaitu $54.5^{\circ} \mathrm{C}$ dipengaruhi oleh kadar zat warna dalam minyak kelapa dan konsentrasi minyak jarak sebesar $20 \%$ yang ditambahkan kedalamnya. Titik leleh yang diperoleh dari pemeriksaan sediaan lipstik ekstrak minyak kelapa kulit melinjo merah memenuhi titik leleh SNI 164769-1998 yaitu $50-70^{\circ} \mathrm{C}$.

\section{Nilai pH}

Pemeriksaan nilai $\mathrm{pH}$ sediaan lipstik untuk mengetahui tingkat keasaman formulasi sediaan lipstik yang dibuat dengan menggunakan $\mathrm{pH}$ meter. Lipstik yang baik mempunyai nilai keasaman mendekati nilai $\mathrm{pH}$ fisiologis kulit bibir yaitu 3.8-4.7 (Vishwakarma et al. 2011). Hasil pemeriksaan pH sediaan lipstik disajikan pada Tabel 9. 
Tabel 9 Nilai $\mathrm{pH}$ sedian lipstik ekstrak minyak kelapa kulit melinjo merah

\begin{tabular}{ccc}
\hline Formulasi & $\mathrm{pH}$ & $\mathrm{pH}\left(\begin{array}{c}\text { 2011) } \\
\text { 2015akma, et al., }\end{array}\right.$ \\
\hline 436 & 3.90 & $3.8-4.7$ \\
158 & 4.08 & \\
790 & 4.10 & \\
632 & 4.27 & \\
\hline
\end{tabular}

Tabel 9 adalah pemeriksaan nilai $\mathrm{pH}$ yang menunjukkan bahwa keempat sediaan lipstik (436, 158, 790 dan 632) mempunyai nilai $\mathrm{pH}$ kisaran 3.9-4.27. Tingkat keasaman meningkat sebanding dengan bertambahnya konsentrasi ekstrak minyak kelapa kulit melinjo merah pada formulasi 436 dan 632 adalah sebesar $53.3 \%$ dan $26.67 \%$. Hal ini menunjukan bahwa perbedaan konsentrasi pewarna ekstrak minyak kelapa kulit melinjo merah yang digunakan bersifat asam. Semakin tinggi konsentrasi ekstrak kulit minyak kelapa kulit melinjo merah yang digunakan menghasilkan nilai $\mathrm{pH}$ sediaan semakin rendah.

\section{Homogenitas Sediaan Lipstik}

Parameter pengujian homogenitas sediaan lipstik untuk melihat ada tidaknya butir-butir kasar atau grity. Adanya butir-butir kasar atau grity menandakan sediaan lipstik yang dibuat tidak homogen karena tidak terdispersinya antar komponen lipstik membentuk susunan yang homogen.

Hasil pemeriksaan homogenitas menunjukkan bahwa seluruh sediaan lipstik menggunakan ekstrak minyak kelapa kulit melinjo merah tidak memperlihatkan adanya butir-butir kasar atau grity saat dioleskan pada kaca transparan. Hal ini menunjukkan bahwa sediaan lipstik ekstrak minyak kelapa kulit melinjo merah mempunyai susunan yang homogen.

\section{Daya Oles}

Sediaan lipstik dikatakan mempunyai daya oles yang baik jika sediaan memberikan warna yang intesif, merata dan homogen saat dioleskan. Daya oles sediaan lipstik ekstrak minyak kelapa kulit melinjo merah dapat dihat pada Gambar 5.

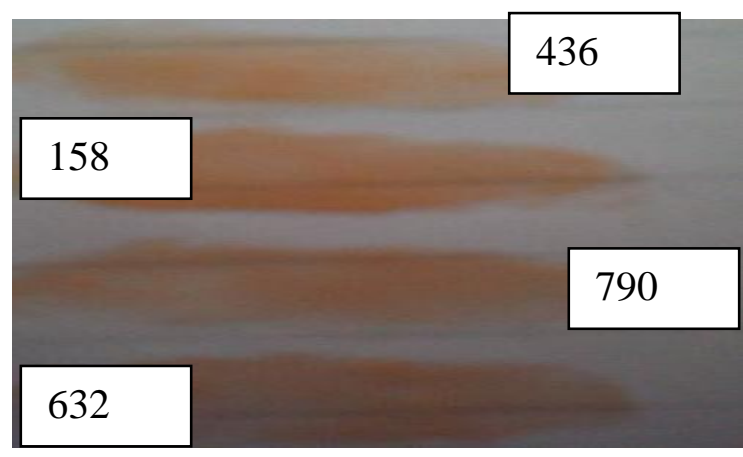

Gambar 5 Hasil uji oles sedian lipstik ekstrak minyak kelapa kulit melinjo merah

Gambar 5 menunjukkan bahwa sediaan yang memiliki daya oles yang baik adalah sediaan 158 yaitu dengan konsentrasi pewarna sebesar $33.3 \%$. Hal ini terlihat dengan pengolesan sediaan memberikan warna yang lebih pekat dan homogen sedangkan sediaan yang lain memberikan warna yang lebih kurang merata dan memberikan warna oranye yang lebih muda.

\section{Mutu Hedonik}

Uji hedonik atau uji kesukaan. Panelis dimintakan tanggapan pribadinya tentang kesukaan atau sebaliknya (ketidaksukaan) dan mengemukakan tingkat kesukaannya dengan skala. Skala hedonik dengan data numeric untuk dapat dilakukan analisis secara statistik. Hasil analisis statistika ANOVA terhadap uji hedonik kepada 20 panelis menunjukkan bahwa keempat formulasi $(436,158,790$ dan 632) tidak berbeda nyata terhadap parameter uji warna, aroma, tekstur dan keseluruhan karena nilai sig $\alpha \geq 0.05$.

Keempat formulasi $(436,158,790$ dan 632) yang dibandingkan dengan lipstik komersil merk $\mathrm{X}$ sebagai kontrol untuk parameter uji warna, aroma, tekstur dan keseluruhan mempunyai daya terima yang baik dengan memperoleh hasil analisa statistika ANOVA yaitu skor diatas 3 (agak suka sampai suka). Parameter kesukaan warna untuk formulasi 790, formulasi 158 untuk aroma, formulasi 632. Rata-rata kesukaan formulasi sediaan lipstik (436, 158, 790 dan 632) terhadap keempat parameter uji yaitu warna, aroma, tekstur dan keseluruhan disajikan pada Gambar 6. 


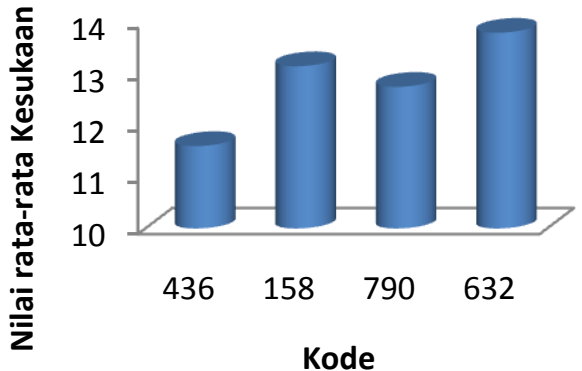

Gambar 6 Diagram batang nilai rata-rata kesukaan

Gambar 6 menunjukkan bahwa kesukaan panelis terhadap keempat formulasi sediaan lipstik yang dibuat adalah formulasi 632 paling disukai dari penjumlahan nilai ratarata warna, aroma, tekstur dan penerimaan keseluruhan dengan nilai rata-rata sebesar 13.80 .

\section{Sifat Iritasi}

Berdasarkan hasil uji iritasi yang telah dilakukan pada 10 orang panelis dengan mengoleskan sediaan lipstik ekstrak minyak kelapa kulit melinjo merah pada kulit punggung tangan dalam waktu selama 10 menit selama 3 hari menunjukkan bahwa gejala yang dialami panelis terhadap sediaan lipstik untuk formulasi 436 hasil negatif atau tidak ada, untuk formulasi 158 dan 632 terdapat satu orang yang merasakan gejala gatal-gatal pada hari uji kedua dan ketiga dan untuk formulasi 790 terdapat dua orang yang merasakan gejala gatal-gatal, satu orang pada hari uji pertama dan satu orang pada uji hari ketiga.

Berdasarkan indeks iritasi dari sediaan lipstik formulasi 436 dengan nilai nol (0), formulasi 158 dan 632 dengan nilai 0.67 dan 790 dengan nilai 1,33 terhadap 10 panelis, nilai indeks iritasi keempat formulasi dapat digolongkan sebagai tidak ada iritasi atau hampir tidak ada iritasi. Keempat formulasi sediaan lipstik aman digunakan dan bukan termasuk lipstik yang berbahaya.

\section{Stabilitas Penyimpanan}

Pengamatan stabilitas sediaan terhadap keempat formulasi sediaan lipstik dilakukan selama 30 hari pada temperatur ruang. Pengamatan disajikan pada tabel 10.

Tabel 10 menunjukkan bahwa pengamatan stabilitas penyimpanan selama 30 hari untuk mengetahui terjadinya perubahan warna, aroma dan tekstu atau bentuk. Selama penyimpanan 30 hari keempat formulasi sdiaan lipstik (436, 158, 790 dan 632) stabil tidak mengalami perubahan warna, aroma dan tekstur atau bentuk. Tanda (+) dalam tabel 10 menunjukkan warna, aroma dan tekstur pada setiap formulasinya karena pengaruh

Tabel 10. Data pengamatan stabilitas penyimpanan

\begin{tabular}{|c|c|c|c|c|c|c|c|c|}
\hline \multirow[t]{2}{*}{ Formulasi } & \multirow[t]{2}{*}{ Paramater } & \multicolumn{7}{|c|}{ Hari Ke- } \\
\hline & & 1 & 5 & 10 & 15 & 20 & 25 & 30 \\
\hline \multirow[t]{3}{*}{436} & Warna & ++ & ++ & ++ & ++ & ++ & ++ & ++ \\
\hline & Aroma & +++ & +++ & +++ & +++ & +++ & +++ & +++ \\
\hline & Tekstur & ++ & ++ & ++ & ++ & ++ & ++ & ++ \\
\hline \multirow[t]{3}{*}{158} & Warna & +++ & +++ & +++ & +++ & +++ & +++ & +++ \\
\hline & Aroma & +++ & +++ & +++ & +++ & +++ & +++ & +++ \\
\hline & Tekstur & +++ & +++ & +++ & +++ & +++ & +++ & +++ \\
\hline \multirow[t]{3}{*}{790} & Warna & + & + & + & + & + & + & + \\
\hline & Aroma & +++ & +++ & +++ & +++ & +++ & +++ & +++ \\
\hline & Tekstur & + & + & + & + & + & + & + \\
\hline \multirow[t]{3}{*}{632} & Warna & ++ & ++ & ++ & ++ & ++ & ++ & ++ \\
\hline & Aroma & +++ & +++ & +++ & +++ & +++ & +++ & +++ \\
\hline & Tekstur & ++ & ++ & ++ & ++ & ++ & ++ & ++ \\
\hline
\end{tabular}

Keterangan : (+) tingkat kepekatan 
perbedaan konsentrasi pewarna ekstrak minyak kelapa kulit melinjo merah dengan minyak jarak.

\section{SIMPULAN}

Formulasi lipstik dengan penambahan konsentrasi pigmen alami melinjo merah tidak banyak memberikan pengaruh secara visual maupun warna yang dioleskan dan hasil pemeriksaan mutu fisik sediaan. Hasil uji menunjukkan bahwa keempat sediaan lipstik yang dibuat memiliki titik leleh $53-54.5{ }^{\circ} \mathrm{C}$, memenuhi syarat mutu lipstik SNI 16-47691998, homogenitasnya baik, memiliki pH 3.94.27 (mendekati $\mathrm{pH}$ kulit), Seluruh sediaan yang dibuat stabil dalam penyimpanan selama 30 hari, tidak menunjukkan adanya perubahan bentuk, warna dan aroma.

Sediaan lipstik yang dibuat tidak mengiritasi dan uji hedonik secara keseluruhan atau daya terima panelis terhadap keempat formulasi paling disukai formulasi 632 dengan konsentrasi pigmen dan minyak jarak sama yaitu konsentrasi sebesar $26.7 \%$.

\section{Saran}

Perlu dilakukan penyempurnaan formulasi lipstik, dilakukan formulasi lipstik dengan ekstrak etanol kulit melinjo merah dengan penambahan emulsifier, dan dilakukan uji cemaran mikroba sebelum dan sesudah penyimpanan 30 hari sebagai pemeriksaan syarat mutu lipsti SNI 16-4769-1998 pada uji evaluasi sediaan.

\section{Daftar Pustaka}

Ansel HC. 1989. Pengantar Bentuk Sediaan Farmasi. Ed Ke-4. UI. Jakarta

Astuti EP. 2011. Efektivitas Minyak Jarak Pagar Sebagai Lavarsida, Anti-Oviposisi Dan Ovisida Terhadap Larva Nyamuk Aedes albopictus. Bul. Littro. 22(1): $44-53$.

Balsam MS, SD Gershon, MM Rieger, E Sagarin, J Stiaries. 1974. Cosmetic, Science and
Technology. New York (US): John Wiley and Sons.

Cornelia M, MS Tagor, Erniziar. Studi Kandungan Carotenoid, Vitamin C Dan Aktivitas Antioksidan Kulit Melinjo (Gnetum gnemon L.). Jakarta (ID): UPH.

Harborne JB. 1987. Metode Fitokimia Penuntun Cara Modern Menganalisis Tumbuhan. Bandung (ID): ITB.

Howard GM. 1974. Perfumes, Cosmetics and Soaps. Ed ke-3. Volume ke-8. London (UK): Chapman and Hall.

Imelda E. 2007. Karakterisasi Fisik dan Uji pH Larutan Rendaman Kulit Melinjo dan Kekerasan Kulit Melinjo. Bogor (ID): FMIPA IPB.

Imron HSS. 1985. Sediaan Kosmetik. Direktorat Pembinaan, Penelitian dan Pengabdian Masyarakat. Jakarta. IPB. 1989. Pigment. Proyek Peningkatan Perguruan Tinggi. Bogor (ID).

Martinalova D. 2004. Pemanfaatan Kulit Buah Pandanus tectorius Sebagai Pewarna Pada Pembuatan Lipstik [Skripsi]. Bogor (ID): Fakultas Perikanan dan Ilmu Kelautan IPB.

Okayani M. 1990. Faktor Titik Leleh Malam, Lemak dan Minyak Zat warna pada Formulasi Sediaan Lipstik. [Skripsi]. Universitas Jakarta. Jakarta.

Perdanakusuma O, Wulandari Z. 2003. Optimasi Proses Pembuatan Lipstik dengan Penambahan Berbagai Konsentrasi Malam Lebah. J. Tek. Ind. Pert. 14 (3): 95-100.

Rahim F. 2011. Pemanfaatan Zat Warna dari Ekstrak Cyphomandra betacea dan Minyak Kelapa Murni dalam Formulasi Lipstik. Scientia. 1(2): 55-63. ISSN : 2087-5045.

SNI 16-4769. 1998. Lipstik. Dewan Standarisasi Nasional. Jakarta.

Vishwakarma B, Dwivedi S, Dubey K, Joshi H. 2011. Formulation and Evaluation of Herbal Lipstick. International Journal of Drug Discovery \& Herbal Research. 